\title{
甲状腺好酸性細胞腫の検討
}

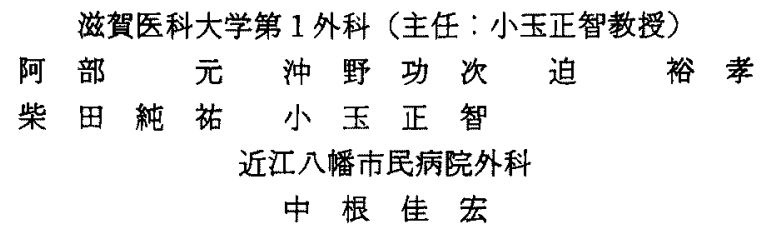

甲状腺好酸性細胞腫は，好酸性顆粒を多数含む特徴的な細胞からなる睡湯で，比較的 稀な疾患である。著者らは 5 例の甲状腺好酸性細胞腫を経験したので，臨床的检討を加 えた。

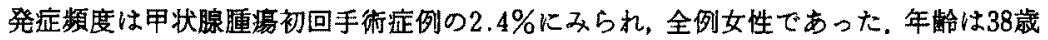
から66歳の平均53.8歳であった，症状は前頙部尰瘤のみで，正迫症状などは認めなかっ た。甲状腺機能は全例正常であり，頸部軟線撮影，超音波検査シシンチグラムでは特徵 的な所見を認めず，良性，悪性の鑑別柱困難であった。腫婸核出術のみは 2 例，葉切除 衍が 3 例に施行された。良性, 悪性の鑑別は細胞形㦔からでは困難であり, 被膜浸潤, 脈管侵㙰の有無で判断した結果, 良性が 4 例, 悪性は1 例であった。全例とも術後経過 良好で，再発を認めていない。

索引用語：甲状腺腫埸，好酸性細胞腺腫，好酸性細胞癌

\section{緒 雷}

甲状腺上皮性腫場の中で，好酸性胞体を持つ腫瑒細 胞から構成されるものは好酸性細胞腫 Oxyphilic cell tumor (Hurthle cell tumor) と呼ばれ，比較的稀な腫 場である。㘯の予後や治療法については，現在もまだ 論議されている。1978年4月から1991年3月までの13 年間に当科で切除された甲状腺揰埸初回手術症例は良 性腫湯99例，悪性腫煌106例の計205例であった。この 万ち好酸性細胞缠は 5 例 (2.4\%) であり，好酸性細胞 腺隀 Oxyphilic cell adenoma は 4 例，好酸性細胞癌 Oxyphilic cell carcinomaは 1 例であった。この5例 について，文献的考察を加えて報告する。

\section{症 例}

症例 $1 ： 48$ 藏，女性。

現病歴：1985年 4 月右頸部腫瘤を自覚した。同年10 月近医にて甲状腺腺腫と診断され，11月当科紹介と なった。

所見：甲状腺右葉上極に $48 \times 36 \mathrm{~mm}$ の表面平滑で弾 性硬，可動性良好な缠㽷を触知した。頸部軟線撮影で

1991年 8 月 8 日受付 1992年 1 月29日採用
は石灰化は認めず，超音波検査では境界明瞙で内容均 一な畽湯を認め，その内部に small cystic lesion が散 在した. ${ }^{123}$ Iンングラムでは右葉上極に cold nodule を認めた。状腺機能は正常であった。

経過：甲状腺腺腫の診断にて，腫場核出術を施行し た。睡瘍は充実性で，大きさは $45 \times 34 \times 32 \mathrm{~mm}$ であっ た。肥厚した被膜を認め, 組織診断は好酸性細胞腺腫 であった(図 1 )。衍後 6 年経過するも再発を認めてい ない。

症例 $2 ： 66$ 藏, 女性.

現病歴：1981年頃右頸部腫瘤に気付き，近医受診す るむ特に異常なしと云われていた，1986年になり腯瘤 が増大してきたため，同年 5 月当科受診した。

所見：甲状腺右葉下極に $65 \times 63 \mathrm{~mm}$ の表面平滑で弾 性軟，可動性良好な皇瘤を触知した。頸部軟線摄影で は石灰化は認めず，超音波検査では境界明膫で内容不 均一な腫瘍であった。 ${ }^{99 m} \mathrm{~T} \mathrm{~T}$ シンキクラムでは右葉下 極に cold noduleを認め, ${ }^{201} \mathrm{Tl}$ シンチダラムでは early scan で強い集皘を認め， delayed scanでる集箖 が残存していた，甲状腺機能は正常であった。

経過：シンチクラムの所見よク，悪性も否定できな 


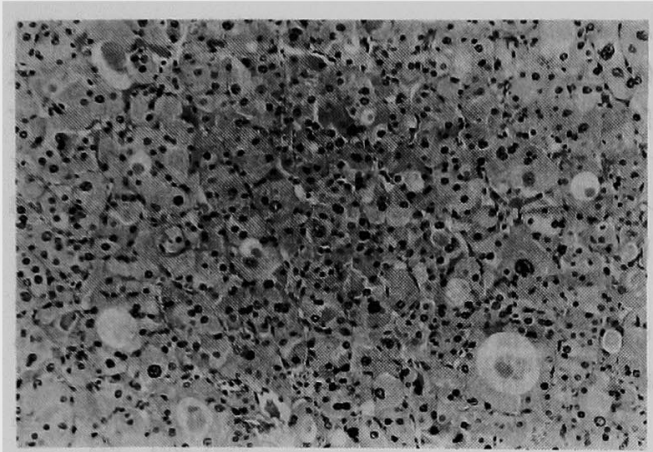

图 1 好酸性細胞腺茞の病理組織像：好酸性顆粒を含 んだ大小不同の練胞が認められ，核の異型性もみら れる (H.E. 染色, $\times 400$ )

いため，右葉切除術を施行した，畽場は全体に軟らか で内容妁一であり,大きさは $78 \times 54 \times 52 \mathrm{~mm}$ であった。 術中迅速検查で好酸性細胞腺腫とされた。最終的な組 織診断す同様であった。術後 5 年経過するも再発は認 めていない.

症例 $3: 37$ 歳, 女性.

現病歴：1983年集団検診にて前頸部腫瘤を指摘され たか，そのまま放置していた，1986年 9 月再度検診で 前䫫部尰虜を指摘され，精查目的にて当科受診した。

所見：甲状腺左葉下極に $13 \times 12 \mathrm{~mm}$ の表面がやゃ粗 で，可動性の乏しい硬い腫瘤を触知した，頸部軟線撮 影では石灰化は認められず，超音波検査では比較的境 界明瞭で，内部に高ェコ一領域を含むが全体に低ェ コー域な尰湯を認めた。 また右葉上極に2 $3 \mathrm{~mm}$ 大の cystic lesion を認めた。 ${ }^{99 \mathrm{~m}} \mathrm{Tc}$ および201 $\mathrm{Tl}$ シンチグラ ムでは病巣は描出されなかった，甲状腺機能は正常で あった。

経過：触診および超音波検査より悪性を疑い，左葉 切除術を施行した．大きさ $12 \times 9 \times 8 \mathrm{~mm}$ の弾性硬で充 実性の腫瘍を認め，肥厚した被膜に被われて，周囲と の恣着も認めなかった，組織診断は好酸性細胞腺腫で あった. 術後 4 年 8 力月経過するも再発は認めていな い.

症例 $4: 52$ 藏, 女性.

現病歴：1988年 2 月集団検診にて右甲状腺腫瘤を指 摘され，同年 3 月当科受診した，腺腫様甲状腺腫の診 断にて経過観察していたが，1989年 1 月超音波検査で 悪性腫湯を疑われたため入院となった。

所見：甲状腺右葉下極の $10 \times 10 \mathrm{~mm}$ の表面平滑, 弾
性硬の可動性やや不良な尰瘤を触知した．頸部軟線撮 影では石灰化は認められず，超音波検查では境界やゃ

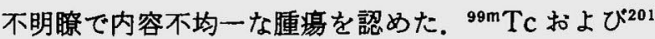
$\mathrm{Tl}$ シンチグラムでは病巣は描出されず, 甲状腺機能は 正常であった.

経過：手術は腫瘍核出術を施行した。腫瘍は $5 \times 3 \times$ $2 \mathrm{~mm}$ で, 硬くて被膜も不明瞭であった。術中武速検査 の結果は好酸性細胞腺腫であり，最終的な組織診断む 同様であった，術後 2 年 4 力月経過するも再発を認め ていない.

症例 5：66歳，女性.

現病歴：1963年頃に頸部腫瘤に気付くが放置してい た. 1981年 5 月高血圧にて本院内科受診した際に，甲 状腺腫を指摘され当科紹介となった。

所見：甲状腺右葉に $70 \times 50 \mathrm{~mm}$ の表面平滑，弾性硬 で, 皮届との㾤着すない可動性良好な腫晹を触知した。 頸部軟線撮影では米粒大の石灰化を認め，気管は著明 に左方に匠排されていた．頸部 CT では右葉上極は solid, 下極は cystic な部分からなる畽場で，周囲はよ く enhanceされ, 周辺組織への痗着, 浸潤は認められ なかった。 ${ }^{123} I$ シンチグラムでは右葉の久損像を認め た，穿刺吸引細胞診では好酸性細胞を認めず, class I であった，甲状腺機能は正常であった。

経過：悪性を否定できないため，峡部を含めた右葉 切除術を施行した，腫場は $70 \times 50 \times 21 \mathrm{~mm}$ と大きく， 表面は多房性で, 中央部は充実性で軟骨様の硬さで あった，周囲への㾈着は認めなかった，術中迅速検査 では好酸性細胞腺腫と診断されたため, リンバ節の郭 清は行わなかった。しかし，最終的な組織では被膜へ の浸潤，および脈管侵裝を認め，好酸性細胞癌と診断

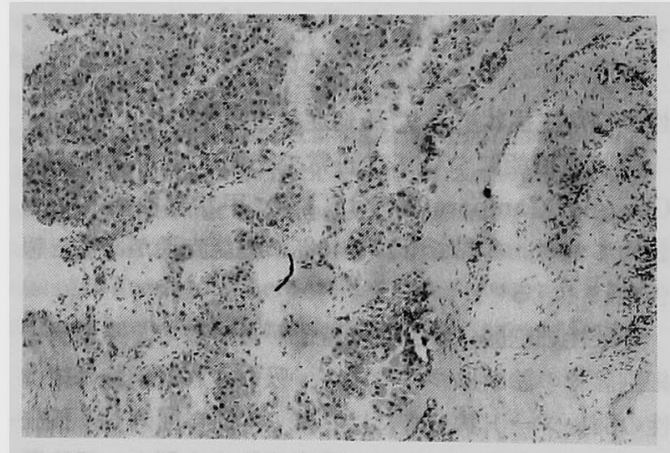

图 2 好酸性細胞癌の病理組織像：好酸性に染まる細 胞が被膜内に浸潤している（H.E. 染色, $\times 100)$ 
された（図 2)，化学療法は行わず，経過䘽察とした， 術後10年経過するも再発を諗めず，現在す健在である。

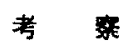

甲状腺好酸性細胞盾は, Oxyphilic cell tumor, eosinophilic cell tumor, Hurthle cell tumor, Askanazy cell tumor とも呼ばれ，好酸性顆粒を含む 大きな胞体を持つのが特徽である。電顕的には著明な ミトコンドリアの增多が見られ，これはミトコンドリ アの過分裂と, life spanの延最によるすのといわれて いる",

好酸性細胞は滤胞細胞起源竟之され，橋本病中 Basedow 病，良性結節にもしばしば見られるが、被膜 により境され，全体ないしその主要部分が好酸性細胞 で占められるすのを好酸性細胞睡とされている。 $\mathrm{WHO}^{3)}$ 括よび本邦の甲状腺癌取扱い規約いでは，好酸 性細胞癌を滤胞癌の一亜型として分類しているか; Woolner ら5) は好酸性細胞を単に乳頭癌または濾胞癌 の二次性変化とみなし，別個には取り扱っていない． また Tollefsen らの゙はリンバ節転移の頻度が高く，放射 性ヨードの取り込みが怪とんど無く， ${ }^{13}$ I治療が無効 であることより，一覀型ではなく独立した型として分 類している.

1898年 Askanazy")によって最初の臨床像が報告さ れたが、1945年までは22例と少なかった。 その後報告 例が增加し，現在諸家の報告では $2 \sim 10 \%$ とされてい る8.．本邦では1953年伊藤ら叫によって報告され，その 頻度は1.2３.2\%とされている10).

男女比について, Frazell ら ${ }^{211}$ は 1：2，Hom ${ }^{121}$ は $1: 2.5$ といずれる女性に多いと報告しており，一般に は男性の $2 \sim 3$ 倍とされている. 発症年龄は, 他の甲 状腺分化癌と比べゃ高年齢層の 40 ０歳代にビーク があるとされて扰り，著者らの結果で 5 例とも女性 で，平均年踚は53.8藏であった。

好酸性紐胞瘇は悢徐な発育を示すため, 前頸部無痛 性瘇瘤が主症状であり，圧迫症状を示すことは少ない。 甲状腺機能については正常であることが多いが，

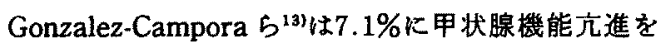
認めており，本邦でる10４0\%に機能六進があると報 告されている10).

好酸性細胞缠は細胞像に特徽があるので，穿刺吸引 細胞診での診断はつけやすい，吸引される細胞は結合 性の弱いシート状，またはロぜット状に配列し，狐立 性細胞も多数認められる。腫瘍細胞は大型で, 細胞質 が好酸性、顆粒状に染まり，多形性に富む。核は円形
ないし卵円形で，クロマチンは顆粒状に凝集し，核小 体か明らかなあのが多い，しかし，細胞形態たけで社 良性と悪性の鑑別がつかないといら報告が活とんど

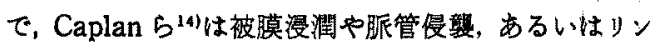
八節転移をるって悪性としている，著者らすこれに準 し，被膜浸潤，脈管侵輩を認めた 1 例を癌とした。

${ }^{201} \mathrm{Tl}$ シンチダラムで early scan, delayed scan もに強い集積を認めるものは悪性が多いという報告も ある15が，特異的ではない，

治療については ${ }^{131} I$ 扰よび化学㙩法は無奻で16)，手 術が第一選択である. Thompson ら ${ }^{17} は 2 \mathrm{~cm}$ 以上の腫

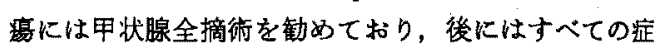
例に全摘術を行っている18). しかし, Bondeson 5 ${ }^{18)}$

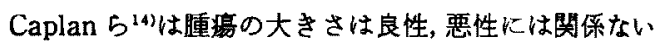
とし，組織学的に良性と猃断されたすのには莱切除術, 悪性とされたすのには垔全摘術を行っている。

好酸性細胞癌の予後について, Tollefsen $\left.5^{6}\right)$ 怯 5 年 生存率 $76 \%, 10$ 年生存率 $60 \%, 15$ 年生存率 $47 \%$ 之報告 している. Har-el 5 201410 年生存率 $63.7 \% ， 15$ 年生存 率25\%として扣り，乳頭癌や满胞癌などの low-grade malignant cancer の 10 年生存率仕 $65 \sim 95 \%$, 未分化㿋 などの high-grade malignant cancer 22 年生存率は $8 \%$ 以下であることより, 好酸性細胞癌を moderate malignancy としている。

著者らは良性とされた症例炕核出術と葉切除政， 悪性とされた症例は浃部を含めた葉切除術を行った が，現在のところ再発は認めていない。

$$
\text { 結語 }
$$

甲状腺好酸性細胞腺尰 4 例，好酸性細胞癌 1 例を経 験したので，若干の文献的考察を加えて報告した。

$$
\text { 文献 }
$$

1) Feldman PS, Hormath E, Kovacs $K$; Ultrastructure of three Hurthle cell tumors of the thyroid. Cancer $30: 1279-1285,1972$

2) Hamperl $H$ : Benign and malignant oncocytoma. Cancer $15: 1019,1962$

3) Hedinger C, Sobin LH: Histological typing of the thyroid tumors. In: International Histological Classification of Tumors, vol 11, World Health Organization, Geneva, 1974, p22

4) 甲状腺外科検討会：外科·病理.甲状腺癌取扱、规 約，第 3 版，金原出版，1988， p 20

5) Woolner LB, Beahrs OH, Black BM, et al: Classification and prognosis of thyroid car- 
cinoma: A study of 885 cases observed in a thirty year period. Am J Surg $102: 354-387$, 1961

6) Tollefsen HR, Shah JP, Huvos AG, et al: Hurthle cell carcinoma of the thyroid. Am J Surg 130: 390-394, 1975

7) Askanazy $M$ : Pathologisch-anatomische Beitrage zur Kenntniss des Morbus Basedowii, insbesondere uber die dabei auftretende MuskelerKrankung. Deutsch Arch f Klin Med 61 : $118-186,1898$

8）葍田史子，山本裕幸，山中泰輝他：Hurthle cell tumorの1例，日生病医誌 15:95-98, 1987

9）尹藤順夫，堀内藤吾，芳賀元子他：Hurthle 氏細胞 隀疸の1例, 東北医学会雜誌 $48: 442-444,1953$

10）建部祥，頁田武保，田宫洋一他：Hurthle 細胞化

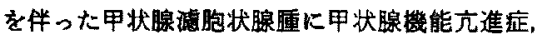
甲状腺乳頭状腺癌を合併した 1 例，外科診噔 30 ： $1113-1116,1988$

11) Frazell EL, Duffy BJ : Hurthle-cell cancer of the thyroid: A review of forty cases. Cancer 4 : 952-956, 1951

12) Hom RC: Hurthle-cell tumors of the thyroid. Cancer $7: 234-244,1954$

13) Gonzalez-Campora R, Herrero-Zapatero A, Lerma $E$, et al: Hurthle cell and mitochondrion-rich cell tumors: A clinicopathologic study. Cancer $57: 1154-1163,1986$

14) Caplan RH, Abellera RH, Kisken WA: Hurthle cell tumors of the thyroid gland: A clinicopathologic review and long term follow up. JAMA $251: 3114-3117,1984$

15) Ochi H, Sawa H, Fukuda T: Thallium 201 chloride thyroid scintigraphy to evaluate benign and/or malignant nodules: Usefulness of the delayed scan. Cancer $50: 236,1982$

16) Miller RH, Estrada R, Sneed WF, et al : Hurthle cell tumors of the thyroid gland. Laryngoscope $93: 884-888,1983$

17) Thompson NW, Dunn EL, Batsakis JG, et al : Hurthle cell lesions of the thyroid gland. Surg Gynecol Obstet 139 : 555-560, 1974

18) Gundry SR, Burney RE, Thompson NW, et al : Total thyroidectomy of Hurthle cell neoplasm of the thyroid. Arch Surg 118: 529-532, 1983

19) Bondeson L, Bondeson AG, Ljungberg O, et al : Oxyphil tumors of the thyroid. Ann Surg 194: $677-679,1981$

20) Har-el G, Hadar T, Segal K, et al : Hurthle cell carcinoma of the thyroid gland : A tumor of moderate malignancy. Cancer $57: 1613-1617$, 1986

\section{FIVE CASES OF OXYPHILIC CELL TUMORS OF THE THYROID}

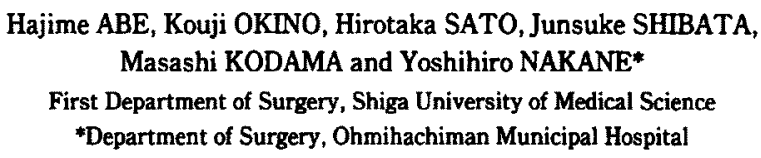

Oxyphilic cell tumors of the thyroid are relatively rare which consist of large cells characterized by marked cytoplastic acidophilia. In this paper recent 5 cases of oxyphilic cell tumor of the thyroid were clinically studied.

The tumors represented $2.4 \%$ of all primary thyroid tumors, and the patients comprised females only with an age ranging from 38 to 66 years (mean 53.8 years). They complained of an anterior neck tumor without compression symptoms, and had normal thyroid function. Preoperative examinations such as neck X-ray, ultrasonography and scintigram could not make a definite diagnosis. Enucleation was carried out in 2 cases and lobectomy in 3 cases. The cellular differentiation between benign and malignant types of the tumors is very difficult, and we used diagnostic criteria for malignancy including capsular or vascular invasion. There were 4 cases of oxyphilic cell adenoma and 1 case of oxyphilic cell carcinoma. The patients have been in good condition and no recurrence can be found. 